\title{
ANALISIS PENERAPAN \\ GOOD CORPORATE GOVERNANCE PADA BANK UMUM SYARIAH BERDASARKAN PERATURAN BANK INDONESIA N0.11/33/PBI/2009
}

\section{ANALYSIS OF IMPLEMENTATION \\ OF GOOD CORPORATE GOVERNANCE ON ISLAMIC BANKS BASED ON BANK OF INDONESIA REGULATION NO. 11/33/PBI/2009}

\author{
Siti Wadiah ${ }^{1 \mathrm{a}}$ Rully Trihantana ${ }^{2 \mathrm{~b}}$ \\ 1aJurusan Ekonomi Islam Fakultas Perbankan Syariah Universitas Djuanda, Jl. Tol Ciawi No. 1 Bogor Kode Pos \\ 16720. \\ 2bJurusan Perbankan Syariah Fakultas Ekonomi Islam Universitas Djuanda, Jl. Tol Ciawi No. 1, Bogor Kode \\ Pos16720 \\ Email : 1a wadhikudo@gmail.com, 2b hantana@yahoo.com
}

(Diterima oleh Dewan Redaksi: Agustus)

(Dipublikasikan oleh Dewan Redaksi: Desember)

\begin{abstract}
The implementation of corporate governance practicesor Good Corporate Governance (GCG) for Islamic banks do not only comply with the legislation in force, but also mean innovation and management improvement on an continious basis in order to improve the GCG principles application quality. Islamic banks corporate governance based on the Bank of Indonesia Regulation No.11/33/PBI/2009 dated December 7, 2009 and Bank Indonesia Circular Letter No.12/13/DPbs dated April 30, 2010 about the implementation of GCG for Islamic Banks and Syariah Unit is the application of the five basic principles: Transparency, Accountability, Responsibility, Professional,, and Fairness. Data collection methods used in this research are questionnaires, interview, and analysis of company documents related to GCG. Results from this research showed that the implementation of the Principles of GCG have been implemented at all levelsor the organization level and are in accordance with the foundation of GCG implementation on Islamic Banks whichis Bank of Indonesia Regulation No. 11/33/PBI/2009.
\end{abstract}

Keywords : Good Corporate Governance (GCG), Principles GCG.

\begin{abstract}
ABSTRAK
Penerapan praktik tata kelola perusahaan yang baik atau Good Corporate Governance (GCG) bagi Bank Umum Syariah bukan semata mematuhi peraturan perundang-undangan yang berlaku namun juga berarti upaya inovasi dan penyempurnaan pengelolaan secara berkelanjutan guna meningkatkan kualitas penerapan prinsip-prinsip GCG. Bank Umum Syariah melaksanakan tata kelola perusahaan dengan berpedoman pada Peraturan Bank Indonesia No.11/33/PBI/2009 tanggal 7 Desember 2009 dan Surat Edaran Bank Indonesia No.12/13/DPbs tanggal 30 April 2010 tentang pelaksanaan GCG bagi Bank Umum Syariah dan Unit Usaha Syariah yaitu penerapan lima prinsip dasar Keterbukaan (Transparency), Akuntabilitas (accountability), Pertanggung jawaban (Responsibility), Profesional (Professional) dan Kewajaran (Fairness).

Metode pengumpulan data yang digunakan dalam penelitian ini adalah dengan menggunakan kuesioner, wawancara, dan analisis dokumen-dokumen perusahaan yang terkait dengan GCG. Hasil dari penelitian ini menunjukan bahwa implementasi prinsip -
\end{abstract}


prinsip GCG telah dilaksanakan pada seluruh tingkatan atau jenjang organisasi dan telah sesuai dengan landasan pelaksanaan GCG pada Bank Umum Syariah yaitu Peraturan Bank Indonesia No. 11/33/PBI/2009.

Wadiah Siti. 2015. Analisis Good Corporate Governance pada Bank Umum Syariah Berdasarkan Peraturan Bank Indonesia No. 11/33/PBI/2009. Jurnal Nisbah(2): 101 - 113.

\section{PENDAHULUAN}

Perbankan adalah segala sesuatu yang mencakup aktivitas bank, kelembagaan bank, kegiatan usaha serta cara dan proses dalam melakukan usahanya. Sedangkan perbankan syariah adalah segala sesuatu yang mencakup aktivitas bank, kelembagaan bank, kegiatan usaha serta cara dan proses dalam melakukan usahanya yang berdasarkan prinsip-prinsip syariah. Bank merupakan suatu badan usaha yang mengimpun dana dari masyarakat dan menyalurkannya kepada masyarakat dalam bentuk kredit (UU No.10 Tahun 1998).

Bank merupakan badan usaha yang bergerak dalam bidang jasa, kepercayaan dari semua pihak yang terkait adalah hal yang sangat penting, baik bagi pemilik dan pengelola bank maupun masyarakat sebagai pengguna jasa bank. Mengkaji peranan bank yang memiliki fungsi sebagai penghimpun dana dari masyarakat dan menyalurkan kembali dana ke masyarakat, terdapat hubungan antara bank dan nasabah yang didasarkan pada unsur kepercayaan dan hukum. Suatu bank hanya dapat melakukan kegiatan dan mengembangkan banknya apabila masyarakat percaya untuk memanfaatkan produk-produk perbankan yang ditawarkan. Kepercayaan dari masyarakat tersebut merupakan modal utama bagi bank untuk dapat memobilisasi dana dari masyarakat.

Krisis perbankan di Indonesia yang dimulai akhir tahun 1997 bukan sematamata diakibatkan oleh krisis ekonomi, tetapi juga diakibatkan oleh belum dilaksanakannya Good Corporate Governance dan etika yang melandasinya. Oleh karena itu, usaha mengembalikan kepercayaan kepada dunia perbankan
Indonesia melalui restrukturisasi dan rekapitalisasi hanya dapat berdampak jangka panjang dan mendasar apabila disertai tiga tindakan penting lain yaitu (Isniarti,2010,263)

1. Ketaatan terhadap prinsip kehati-hatian.

2. Pelaksanaan Good Corporate Governance(GCG)

3. Pengawasan yang efektif dari Otoritas Pengawas Bank.

Perbankan Syariah sebagai lembaga dengan aransemen profit dan loss sharing di mana dalam semua aktivitasnya harus mentaati hukum syariah. Maka penerapan GCG di lembaga perbankan syariah menjadi sebuah keniscayaan yang tak terbantahkan.

Pelaksanaan GCG pada industri perbankan syariah harus berlandaskan lima prinsip dasar, pertama transparansi (Transparency), yaitu keterbukaan dalam mengemukakan informasi yang material dan relevan serta keterbukaan dalam proses pengambilan keputusan. Kedua akuntanbilitas (Accountability) yaitu kejelasan fungsi dalam pelaksanaan pertanggungjawaban organ bank sehingga pengelolaannya berjalan secara efektif. Ketiga (Responsibility) yaitu kesesuaian pengelolaan bank dengan peraturan perundang-undangan yang berlaku dan prinsip-prinsip pengelolaan bank yang sehat. Keempat Independen (Independency) yaitu memiliki kompetensi, mampu bersifat objektif dan bebas dari pengaruh dan tekanan dari pihak manapun serta memiliki komitmen yang tinggi untuk mengembangkan bank syariah. Kelima kewajaran (Fairness) yaitu keadilan dan kesetaraan dalam memenuhi hak-hak stakeholders berdasarkan perjanjian dan peraturan perundang-undangan yang berlaku. (PBI No.11/33/PBI/2009). 
Penerapan kelima prinsip dasar tersebut maka bank syariah wajib berpedoman pada berbagai ketentuan dan persyaratan yang terkait dengan pelaksanaan GCG. Selain itu dalam pelaksanakan GCG, industri perbankan syariah juga harus memenuhi prinsip syariah . Ketidaksesuaian tata kelola bank dengan prinsip syariah akan menimbulkan berbagai risiko terutama risiko reputasi bagi industri perbankan syariah.

Pelaksanaan GCG perbankan syariah tidak hanya dimaksudkan untuk memperoleh pengelolaan bank yang sesuai dengan lima prinsip dasar dan sesuai dengan prinsip syariah, akan tetapi ditujukan untuk kepentingan yang lebih luas. Kepentingan ini antara lain adalah untuk melindungi kepentingan stakeholders dan meningkatkan kepatuhan terhadap peraturan perundang-undangan yang berlaku serta nilai-nilai etika yang berlaku secara umum pada industri perbankan syariah.

\section{MATERI DAN METODE}

Penelitian ini menggunakan metode kualitatif. Metode kualitatif dapat diartikan sebagai metode penelitian berdasarkan pada filsafat positivisme.

Populasi menunjukkan semua jenis kumpulan yang terdapat terdiri dari orang, kejadian atau benda yang diteliti, sampel terdiri dari beberapa anggota yang dipilih dari populasi (wibisono,2006). Di dalam penelitian yang menjadi populasi penelitian adalah peraturan Bank Indonesia No. 11/33/PBI/2009. Dan Sampel pada penelitian ini adalah pasal 8, pasal 23, pasal 47, pasal 52, pasal 53, pasal 54, pasal 55, pasal 56, dan pasal 57.

Teknik pengumpulan data dalam penelitian ini berupa :

Dalam penelitian ini peneliti mengumpulkan data yang dibutuhkan dengan menggunakan beberapa teknik yaitu :

1. Tinjauan Kepustakaan (Library Research), yaitu metode pengu,pulan data yang dilakukan dengan cara mengumpulkan dan menelaah literatur yang berhubungan dengan masalah yang dibahas untuk mendapatkan kejelasan dalam upaya penyusunan landasan teori yang digunakan sebagai pijakan dalam pemecahan masalah. Literature tesebut dapat berupa buku-buku, Koran atau majalah, internet serta sumber lain yang dapt dijadikan acuan dalam penelitian ini.

2. Penelitian Lapangan, yaitu pengumpulan data yang dilakukan dengan cara mengadakan pengamatan secara langsung terhadap objek penelitian dengan teknik :

a. Wawancara

Esterberg (2002) Wawancara merupakan pertemuan dua orang untuk bertukar informasi dan ide melalui tanya jawab, sehingga dapat dikonstruksikan makna dalam suatu topik tertentu. Dalam penelitian ini metode wawancara yang digunakan adalah wawancara baku terbuka yaitu wawancara terstruktur. Wawancara terstruktur pada penelitian ini diawali dengan peneliti menetapkan sendiri masalah dan pertanyaan pertanyaan yang akan diajukan. Wawancara dilakukan dengan unit kerja perusahaan yang memang membawahi bidang kepatuhan terhadap prinsip-prisip Good Corporate Governance.

b. Kuesioner

Kuesioner digunakan untuk mengetahui apakah Bank Umum Syariah telah menerapkan Good Corporate Governance.

Jenis data yang digunakan dalam penelitian ini terdiri atas data primer dan data sekunder. Data-data tersebut diperoleh melalui :

1. Data primer

Data primer dalam penelitian ini adalah Peraturan Bank Indonesia No 11/33/PBI/2009. 
2. Data Sekunder

Dalam penelitian ini dilakukan pula studi kepustakaan yaitu dengan mempelajari buku pustaka, literatur, materi kuliah, artikel, jurnal, skripsi, dan sumber lain yang berkaitan erat dengan penelitian ini.

Teknik analisis data pada penelitian ini adalah Model Miles and Huberman yaitu dilakukan secara interaktif dan berlangsung terus menerus secara tuntas, sehingga datanya sudah jenuh. Model Miles and Huberman saat penelitian berlangsung dan setelah pengumpulan data periode tertentu. Aktivitas dalam analisis data yaitu data reduction, data display, dan conclusion drawing/verification. Langkah-langkah analisis ditunjukkan pada model interaktif dalam analisis data berikut :

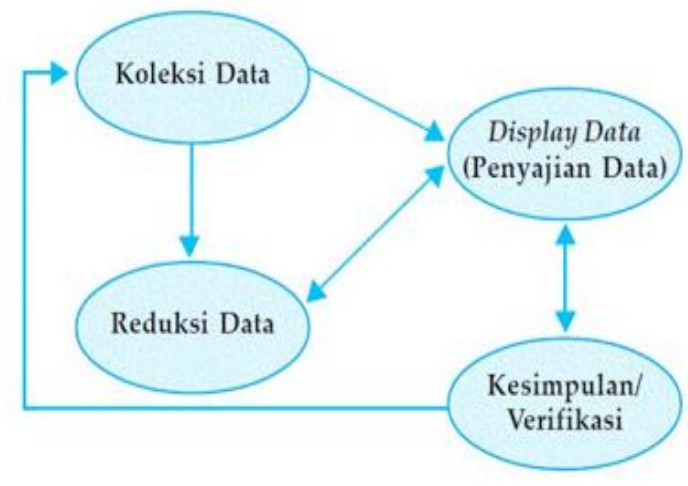

Gambar 1. Analisis Data kualitatif menurut Miles dan Huberman Sumber : Sugiyono, 2010:431

Perhitungan atas kuesioner dilaksanakan dengan menggunakan rumus Dean J, Champion, yaitu dengan menjumlahkan jawaban "YA" kemudian dilakukan perhitungan dengan cara sebagai berikut :

$$
\text { Persentase }=\frac{\sum \text { Jawaban "YA" }}{\sum \text { Jml. kuesioner X Jml Pertanyaan }} \quad \mathrm{X} 100 \%
$$

\section{Keterangan :}

$\Sigma$ Jawaban "YA" : Seluruh penjumlahan jawaban YA yang dijawab oleh reponden dalam kuesionner
$\Sigma$ Jml. Kuesioner : Seluruh penjumlahan kuesioner yang beredar yang wajib diisi oleh para responden.

Jumlah pertanyaan : Pertanyaan yang ada dalam kuesioner berdasarkan klasifikasinya masing masing.

Hasil perhitungan kuesioner sehubungan dengan analisi, dapat diklasifikasikan secara umum yaitu :

1. Kriteria penilaian dari hasil kuesioner yang berkaitan dengan penerapan Good Corporate Governanace.

Tabel 1. Kriteria Penilaian Penerapan Good Corporate Governance

\begin{tabular}{|c|c|}
\hline Persentase & \multicolumn{1}{|c|}{ Kriteria } \\
\hline $0 \% \cdot 25 \%$ & Good Corporate Governance Tidak Terwujud \\
\hline $26 \%: 50 \%$ & Good Corporate Governance Kurang Terwujud \\
\hline $51 \% \% \cdot 75 \%$ & Good Corporate Governance Cukup Terwujud \\
\hline $76 \% \cdot 100 \%$ & Good Corporate Governance Sangat Tewujud \\
\hline
\end{tabular}

Sumber : Dean J. Champion, 1990

\section{HASIL DAN PEMBAHASAN}

Untuk melakukan penelitian atas penerapan Good Corporate Governance pada Bank Umum Syariah berdasarkan pada peraturan Bank Indonesia No.11/PBI/33/2009, peneliti mencari data tertulis dengan cara melakukan pengamatan dari laporan tahunan Bank Syariah Mandiri dan Bank BNI Syariah mengenai pelaksanaan GCG, wawancara dengan staf yang membawahi GCG dan menyebarkan kuesioner kepada kepala dan staf di Bank Syariah Mandiri Cabang Bogor dan Bank BNI Syariah Cabang Bogor. Ketiga cara tersebut dianggap cukup praktis dalam melakukan penelitian. Dan berdasarkan penelitian yang dilakukan penelitian tentang "penerapan Good Corporate Governance pada bank Umum Syariah berdasarkan

PBI 
No.11/PBI/33/2009" maka diperoleh Informasi sebagai berikut:

\section{Analisis Data}

\section{a.Penilaian yang berkaitan dengan penerapan Good Corporate Governance (GCG)}

\section{1). Transparansi}

Transparansi adalah Keterbukaan dalam melaksanakan proses pengambilan keputusan dan keterbukaan dalam mengemukakan informasi materiil dan relevan mengenai perusahaan.

Tabel 2. Perhitungan persentase terhadap transparansi berdasarkan hasil jawaban kuesioner

\begin{tabular}{|c|c|c|c|}
\hline Pertanyaan & $\begin{array}{l}\text { Jawabaı } \\
\text { YA }\end{array}$ & $\begin{array}{l}\text { Jawaban } \\
\text { TIDAK }\end{array}$ & TOTAL \\
\hline 1 & 20 & - & 20 \\
\hline 2 & 20 & - & 20 \\
\hline 3 & 20 & - & 20 \\
\hline 4 & 1 & 19 & 20 \\
\hline 5 & 20 & - & 20 \\
\hline 6 & 20 & - & 20 \\
\hline 7 & 8 & 12 & 20 \\
\hline 8 & 18 & 2 & 20 \\
\hline 9 & 20 & - & 20 \\
\hline 10 & 20 & - & 20 \\
\hline Jumlah & 167 & 33 & 200 \\
\hline \multicolumn{4}{|c|}{ umber : Data diolah } \\
\hline \multicolumn{2}{|c|}{$\%$ Transparansi $=$} & \multicolumn{2}{|c|}{ X $100 \%=83,5 \%$} \\
\hline
\end{tabular}

Berdasarkan perhitungan di atas diperoleh persentase secara keseluruhan sama dengan 83,5 \%, sehingga dapat ditarik kesimpulan bahwa prinsip transparansi pada Bank Umum Syariah Sangat terwujud.

\section{2) Akuntabilitas}

Akuntabilitas adalah Kejelasan fungsi, struktur, sistem, dan pertanggungjawaban organ perusahaan sehingga pengelolaan perusahaan terlaksana secara efektif.
Tabel 3. Perhitungan persentase terhadap Akuntabilitas berdasarkan hasil jawaban kuesioner

\begin{tabular}{llll}
\hline Pertanyaan & $\begin{array}{l}\text { Jawaban } \\
\text { YA }\end{array}$ & $\begin{array}{l}\text { Jawaban } \\
\text { TIDAK }\end{array}$ & TOTAL \\
\hline 1 & 20 & - & 20 \\
2 & 20 & - & 20 \\
3 & 20 & - & 20 \\
4 & 20 & - & 20 \\
5 & 20 & - & 20 \\
6 & 20 & - & 20 \\
7 & 20 & - & 20 \\
8 & 20 & - & 20 \\
9 & 20 & - & 20 \\
10 & 20 & - & 20 \\
Jumlah & $\mathbf{2 0 0}$ & - & $\mathbf{2 0 0}$ \\
\hline
\end{tabular}

Sumber : Data diolah

$\%$ Akuntabilitas $=\frac{200}{200} \times 100 \%=100 \%$

Berdasarkan perhitungan di atas diperoleh persentase secara keseluruhan sama dengan $100 \%$, sehingga dapat ditarik kesimpulan bahwa prinsip Akuntabilitas pada Bank Umum Syariah Sangat terwujud.

Prinsip akuntabilitas ini memuat kewenangan-kewenangan yang harus dimilki oleh dewan komisaris dan direksi beserta kewajiban-kewajibannya kepada pemegang saham dan stakeholders lainnya. Dewan direksi bertanggungjawab penuh atas pelaksanaan pengelolaan BUS berdasarkan prinsip kehati-hatian dan prinsip syariah. Dewan komisaris bertanggungjawab atas keberhasilan pengawasan dan wajib memberikan nasihat dan masukan kepada direksi atas pengelolaan perusahaan sehingga tujuan dapat tercapai.

\section{3) Pertanggungjawaban (Responsibility)}

Kesesuaian (kepatuhan) di dalam pengelolaan perusahaan terhadap prinsip korporasi yang sehat serta peraturan perundang- undangan yang berlaku. 
Tabel 4. Perhitungan persentase terhadap Pertanggungjawaban berdasarkan hasil jawaban kuesioner

\begin{tabular}{llll}
\hline Pertanyaan & $\begin{array}{l}\text { Jawaban } \\
\text { YA }\end{array}$ & $\begin{array}{l}\text { Jawaban } \\
\text { TIDAK }\end{array}$ & TOTAL \\
\hline 1 & 20 & - & 20 \\
2 & 16 & 4 & 20 \\
3 & 20 & - & 20 \\
4 & 20 & - & 20 \\
5 & 20 & - & 20 \\
Jumlah & $\mathbf{9 6}$ & $\mathbf{4}$ & $\mathbf{1 0 0}$ \\
\hline
\end{tabular}

Sumber : Data diolah

$$
\% \text { Responsibility }=\frac{96}{100} \quad \text { X } 100 \%=96 \%
$$

Berdasarkan perhitungan di atas diperoleh persentase secara keseluruhan sama dengan $96 \%$, sehingga dapat ditarik kesimpulan bahwa prinsip Responsibility pada Bank Umum Syariah Sangat terwujud.

Prinsip

pertanggungjawaban (Responsibility) ini menuntut bank melakukan kegatan operasionalnya secara bertanggungjawab. Selain itu bentuk Responsibility pada Bank Umum Syariah juga diwujudkan dalam Corporate Sosial Responsibilty (CSR). CSR adalah praktik bisnis yang didasari oleh nilai-nilai etika, memberikan perhatian kepada seluruh stakeholder serta kepada masyarakat luas.

\section{4) Independen (Independency)}

Suatu keadaan dimana perusahaan dikelola secara profesional tanpa benturan kepentingan dan pengaruh atau tekanan dari pihak manajemen yang tidak sesuai dengan peraturan dan perundanganundangan yang berlaku dan prinsip-prinsip korporasi yang sehat.

Tabel 5. Perhitungan persentase terhadap Independen berdasarkan hasil jawaban kuesioner

\begin{tabular}{llll}
\hline Pertanyaan & $\begin{array}{l}\text { Jawaban } \\
\text { YA }\end{array}$ & $\begin{array}{l}\text { Jawaban } \\
\text { TIDAK }\end{array}$ & TOTAL \\
\hline 1 & 20 & - & 20 \\
2 & 20 & - & 20 \\
3 & 20 & - & 20 \\
4 & - & 20 & 20 \\
5 & 20 & - & 20 \\
Jumlah & $\mathbf{8 0}$ & $\mathbf{2 0}$ & $\mathbf{1 0 0}$ \\
\hline
\end{tabular}

Sumber : Data diolah

$$
\% \text { Independen }=\frac{80}{100} \times 100 \%=80 \%
$$

Berdasarkan perhitungan diatas diperoleh persentase secara keseluruhan sama dengan $80 \%$, sehingga dapat ditarik kesimpulan bahwa prinsip professional pada Bank Umum Syariah Sangat terwujud.

Berdasarkan perhitungan diatas diperoleh persentase secara keseluruhan sama dengan $80 \%$, sehingga dapat ditarik kesimpulan bahwa prinsip professional pada Bank Umum Syariah Sangat terwujud.

Prinsip kemandirian ini menuntut para pengelola bank agar dapat bertindak mandiri sesuai peran dan fungsi yang dimilikinya tanpa ada tekanan dari pihak manapun yang tidak sesuai dengan sistem operasional perusahaan yang berlaku.

\section{5) Kewajaran (Fairness)}

Kewajaran (Fairness) adalah Perlakuan yang adil dan setara di dalam memenuhi hak-hak stakeholders yang timbul berdasarkan perjanjian serta peraturan perundangan yang berlaku.

Tabel 6. Perhitungan persentase terhadap Kewajaran berdasarkan hasil jawaban kuesioner

\begin{tabular}{llll}
\hline Pertanyaan & $\begin{array}{l}\text { Jawaban } \\
\text { YA }\end{array}$ & $\begin{array}{l}\text { Jawaban } \\
\text { TIDAK }\end{array}$ & TOTAL \\
\hline 1 & 20 & - & 20 \\
2 & 20 & - & 20 \\
3 & 20 & - & 20 \\
4 & 20 & - & 20 \\
5 & 20 & - & 20 \\
6 & 16 & 4 & 20 \\
7 & 20 & - & 20 \\
8 & 20 & - & 20 \\
9 & 20 & - & 20 \\
10 & 20 & - & 20 \\
Jumlah & $\mathbf{1 9 6}$ & $\mathbf{4}$ & $\mathbf{2 0 0}$ \\
\hline
\end{tabular}

Sumber : Data diolah

\% Fairness $=\quad \frac{196}{200} \quad$ X $100 \%=98 \%$

Berdasarkan perhitungan di atas diperoleh persentase secara keseluruhan 
sama dengan $98 \%$, sehingga dapat ditarik kesimpulan bahwa prinsip kewajaran pada Bank Umum Syariah Sangat terwujud.

Prinsip kewajaran ini menuntut seluruh pemangku kepentingan harus memiliki kesempatan untuk mendapatkan perlakuan adil dari perusahaan. Pemberlakuan prinsip ini mencegah praktik-praktik tercela yang dilakukan oleh orang dalam yang merugikan pihak lain. Setiap anggota direksi harus melakukan keterbukaan jika menemukan transaksi-transaksi yang mengandung benturan kepentingan.

\section{b. Analisis data yang berkaitan dengan Peraturan Bank Indonesia No. 11/33/PBI/2009.}

\section{1) Pelaksanaan tugas dan tanggungjawab Dewan Komisaris dan Direksi.}

Berdasarkan hasil wawancara dengan responden A selaku salah satu karyawan pada unit kerja yang membawahi bidang GCG pada tanggal 13 Mei 2015, beliau mengatakan :

“ Pengawasan yang dilakukan Direksi pada Bank Syariah Cabang Bogor dilakukan 3 kali dalam setahun, pengawasan dilakukan pada kegiatan operasional seperti dalam hal pendanaan, pembiayaan dan layanan kepada nasabah. Pengawasan juga dilakukan terhadap kepatuhan pegawai agar sesuai peraturan yang berlaku. “

Dalam laporan pelaksanaan Good Corporate Governance tahun 2014:

Dewan komisaris senantiasa melaksanakan tugas dan tanggungjawabnya secara professional dan independen. Dewan komisaris memberikan pendapat, saran, dan nasihat mengenai laporan kinerja dan masalah yang terjadi, termasuk pelaksanaan rencana kerja berikutnya.

Dari perrnyataan diatas, jika dikaitkan dengan PBI No.11/33/PBI/2009 pelaksanaan tugas dan tanggungjawab Dewan komisaris sejalan dengan peraturan Bank Indonesia No. 11/33/PBI/2009 pasal 8 mengenai pengawasan dewan komisaris terhadap direksi dan memberikan nasihat kepada direksi.

2) Kelengkapan dan Pelaksanaan tugas komite-komite dan fungsi yang menjalankan pengendalian intern BUS

Dalam rangka mendukung efektivitas pelaksanaan tugas dan tanggung jawab Dewan komisaris serta implementasi tata kelola perusahaan yang baik (Good Corporate Governance ) sebagaimana diatur dalam peraturan Bank Indonesia no 11/33/PBI/2009 tanggal 7 Desember 2009 tentang pelaksanaan GCG bagi Bank Umum Syariah dan Unit Usaha Syariah, Dewan Komisaris telah membentuk komite audit, komite pemantau risiko, komite remunerasi dan nominasi.

\section{a) Komite Audit}

Susunan anggota komite audit telah memenuhi persyaratan yang telah ditetapkan dalam PBI No 8/4/PBI/2006 tentang pelaksanaan GCG bagi Bank Umum sebagaimana telah diubah berdasarkan peraturan Bank Indonesia no 8/14/PBI/2006 tanggal 5 Oktober 2006 dan diubah terakhir berdasarkan peraturan Bank Indonesia No 11/33/PBI/2009 tanggal 7 Desember 2009 tentang pelaksanaan GCG bagi Bank Umum Syariah dan Unit Usaha Syariah. Persyaratan tersebut adalah anggota komite audit paling kurang terdiri dari seorang komisaris independen, seorang pihak independen yang memiliki keahlian dibidang keuangan dan akuntansi dan seorang dari pihak independen yang memiliki keahlian dibidang hukum atau perbankan. Dalam melaksanakan tugasnya, komite audit selalu berpedoman pada rencana kerja yang telah disusun. rencana kerja yang telah disusun antara lain

1. Independensi anggota komite audit Seluruh anggota komite audit yang berasal dari pihak independen tidak memiliki hubungan keuangan, kepengurusan, kepemilikan saham, dan/pemegang saham pengendali atau hubugan dengan Bank, yang dapat 
mempengaruhi kemampuan bertindak independen:

Tugas dan tanggungjawab komite audit : Sebagai panduan komite audit untuk melaksanakan tugas maka Dewan Komisaris telah menetapkan piagam komite audit (Audit Committee Charter) yang disahkan pada tanggal 20 mei 2005 dan direvisi pada tanggal 4 Desember 2014. Tugas dan tanggungjawab komite audit yang tercantum pada piagam komite audit (Audit Committee Charter) telah sesuai dengan keputusan ketua BAPEPAM No Kep-29/PM/2004. Tugas komite audit adalah sebagai berikut :

a. Melakukan penelaahan atas informasi keuangan yang akan dikeluarkan perusahaan seperti laporan keuangan proyeksi dan informasi keuangan lainnya sesuai dengan standar akuntansi yang berlaku dan pemenuhan pengungkapan yang sesuai peraturan yang berlaku;

b. Melakukan penelaahan atas ketaatan perusahaan terhadap peraturanperaturan perundang-undangan lainnya yang berhubungan dengan kegiatan perusahaan.

c. Melakukan penelaahan atas penerapan GCG.

d. Mengevaluasi efektivitas perusahaan audit dari auditor ekstern termasuk menelaah independensi dan objektivitas auditor ekstern serta menelaah kecukupan pemeriksaan yang dilakukannya memonitor kinerja auditor ekstern dan memastikan kepatuhan terhadap standar professional serta memonitor tindakan tindak lanjut hasil audit.

e. Melakukan penelaahan atas tindak lanjut atas laporan hasil audit yang dilakukan oleh otoritas pengawas Bank, pasar modal dan instansi lainnya.

\section{b) Komite Remunerasi dan Nominasi}

Komite Remunerasi dan nominasi pada bank umum syariah telah sesuai dengan PBI No. 11/33/PBI/2009.

\section{c) Komite Pemantau Risiko}

Komite Pemantau Risiko pada bank umum syariah telah sesuai dengan PBI No. 11/33/PBI/2009.

\section{3) Pelaksanaan tugas dan tanggungjawab Dewan Pengawas Syariah (DPS)}

Secara garis besar Dewan Pengawas Syariah (DPS) melaksanakan tugas dan tanggungjawab sesuai dengan prinsipprinsip GCG, serta memberikan saran dan nasihat kepada direksi terkait dengan pelaksanaan kegiatan bank agar sesuai dengan prinsip syariah. Dewan pengawas syariah diangkat dan disahkan melalui RUPS sesuai dengan rekomendasi dari Dewan Syariah Nasional (DSN).

Menurut pemaparan salah satu karyawan BNI Syariah Cabang Bogor yang membawahi bidang GCG "Dewan Pengawas Syariah berperan aktif dalam mengawasi kegiatan di BNI Syariah Cabang Bogor, DPS berkunjung ke kantor Bank BNI Syariah Cabang Bogor satu tahun sekali, pengawasan yang dilakukan dalam hal pembiayaan , menilai dan memastikan pemenuhan prinsip syariah atas produk yang dikeluarkan bank"

Peran aktif Dewan Pengawas syariah juga dikemukakan oleh responden $\mathrm{A}$ di Bank Syariah Mandiri Cabang Bogor pada wawancara tanggal 13 Mei 2015 :

"DPS datang ke kantor cabang Bogor satu tahun sekali untuk melakukan pengawasan mengenai kesesuaian produk dengan prinsip syariah dan pembiayaan yang diberikan. DPS juga mencoba meningkatkan pemahaman praktik perbankan syariah dengan melakukan dialog dengan pimpinan dan pegawai cabang, sehingga kendala-kendala bisnis dan operasional cabang yang berkaitan dengan aspek syariah dapat diselesaikan."

Pernyataan yang dikemukakan di atas sejalan dengan Peraturan Bank Indonesia No.11/33/PBI/2009 mengenai pelaksanaan Good Corporate Governance bagi Bank Umum Syariah dan Unit Usaha 
Syariah bagian keempat tentang Dewan Pengawas Syariah

\section{4). Penerapan Fungsi Kepatuhan, Audit Intern dan Audit Ekstern}

a. Fungsi kepatuhan adalah serangkain tindakan atau langkah-langkah yang bersifat pencegahan (prefentif) untuk memastikan bahwa kebijakan, sistem dan prosedur serta kegiatan usaha yang dilakukan bank telah sesuai dengan ketentuan Otoritas Jasa Keuangan (OJK), Bank Indonesia dan peraturan perundangundangan yang berlaku, termasuk prinsip syariah bagi bank umum syariah, serta memastikan kepatuhan bank terhadap komitmen yang dibuat bank kepada Bank Indonesia atau otoritas pengawas lain ang berwenang.

Berdasarkan PBI No.11/33/PBI/2009 Bagian Kelima mengenai fungsi kepatuhan, audit intern dan audit ekstern pasal 52 yang berbunyi : " BUS wajib memiliki 1 (satu) orang direktur yang bertugas untuk memastikan kepatuhan terhadap ketentuan Bank Indonesia dan peraturan perundang-undangan lainnya sebagaimana diatur dalam ketentuan Bank Indonesia mengenai direktur kepatuhan."

Laporan tahunan BNI Syariah tahun2014 menjelaskan bahwa "Satuan kerja kepatuhan merupakan unit kerja independen yang membantu pelaksanaan tugas dari direktur kepatuhan dalam menjalankan fungsi kepatuhan di BNI Syariah. Satuan kerja kepatuhan (compliance desk) saat ini menjadi bagian dari legal, compliance dan corporate secretary division."

Laporan pelaksanaan GCG Bank Syariah Mandiri dijelaskan bahwa : "Satuan kerja kepatuhan dalam bank merupakan satuan kerja yang berfungsi melakukan pengawasan dan pengujian, kepatuhan, mengembangkan sistem kepatuhan, serta memonitoring penerapan prinsip mengenal nasabah serta pelaksanaan GCG."

Dalam membangun budaya kepatuhan bank telah melakukan langkah-langkah untuk mendukung terciptanya budaya kepatuhan diantaranya :

1. Penerbitan piagam kepatuhan, yakni dokumen kepatuhan yang bersifat strategi dan berisi panduan, peraturan, kaidah dan kebijakan bank yang wajib dipatuhi oleh jajaran bank.

2. Penerbitan kebijakan kepatuhan, yakni rangkaian asas yang menjadi garis besar dan rencana pelaksanaan fungsi kepatuhan bank.

3. Sistem kepatuhan bank, yakni perangkat pendukung yang telah ditetapkan oleh bank dalam bentuk standar atau manual kerja maupun yang berbasis teknologi untuk mendukung pelaksanaan kepatuhan bank.

\section{b. Audit Intern}

Fungsi audit internal dijalankan oleh Internal Audit Division (IAD) sebuah unit setingkat divisi yang bertanggungjawab langsung kepada direktur utama. Melalui IAD, Direksi dapat memperoleh data /informasi yang independen untuk menilai dan mengevaluasi berbagai kegiatan operasional serta mengambil langkahlangkah yang diperlukan.

Persiapan audit dilaksanakan berbasis pada hasil analisis risiko (risk based) terhadap proses bisnis dan audit bisnis yang diperkirakan memiliki risiko yang signifiakan dalam pencapaian tujuan perusahaan. Data - data audit dari sejumlah system informasi perusahaan diolah sedemikian rupa sehingga mengarah pada sejumlah risiko utama (key risk) yang selanjutnya digunakan dalam menentukan jumlah sampel audit yang dapat mewakili (refresentatif) terhadap keseluruhan ativitas atau transaksi yang diperiksa (objek audit). Penentuan objek dan ruang lingkup audit dicantumkan pada surat tugas tim audit dan laporan atas aktivitas audit.

Aktivitas audit dilakukan dengan menerapkan beragam teknik pengujian audit serta penggunaan analisa pembanding. Selain itu juga dilakukan 
metode surprise dimana metode audit dilakukan tanpa adanya pemberitahuan terlebih dahulu kepada cabang/unit yang akan diaudit. Sedangkan metodologi audit teknologi informasi mengacu pada COBIT (Control Objective for Information and Related Technologi) yang dikembangkan oleh ITGI (IT Governance Institute) yang merupakan bagian dari ISACA (Information System Audit and Control Association.

c. Audit Eksternal

Auditor eksternal ditunjuk untuk melakukan audit finansial serta untuk memberikan pendapat yang independen dan objektif mengenai kewajaran, ketaatazasan dan kesesuaian laporan keuangan perusahaan dengan Standar Akuntansi Keuangan Indonesia dan peraturan perundang-undangan yang berlaku.

Dalam rangka keperluan audit tahun buku 2014, pemegang saham melalui RUPS Tahunan 2013 menyetujui untuk menunjuk Kantor Akuntan Publik yang sama dengan yang digunakan oleh PT Bank Negara Indonesia (Persro) Tbk, selaku perusahaan Induk, yaitu Kantor Akuntan Publik Tanudiredja, Wibisana \& Rekan (afiliasi PwC) untuk menjadi auditor eksternal terhadap pelaporan kinerja keuangan untuk tahun buku 2014.

Kantor Akuntan Publik yang ditunjuk oleh PT. Bank Syariah Mandiri adalah KAP Ernst dan young afiliasi Purwantono, Sarwoko, dan Surja yang telah melalui proses seleksi antara Accounting Division, Komite Audit, Direksi dan Komisaris sebelum diajukan dalam RUPS.

\section{6) Batas Maksimum Penyaluran Dana}

Menurut Peraturan Bank Indonesia No. 7/3/PBI/2005 tentang Batas Maksimum Pemberian Kredit (BMPK), Bank diwajibkan untuk menyampaikan laopran atas Batas Maksimum Penyaluran Dana (BMPD) kepada Bank Indonesia secara teratur dan tepat waktu.
Tabel 7. Batas Maksimum Penyaluran Dana PT. BNI Syariah

\begin{tabular}{|c|l|r|r|r|r|}
\hline \multirow{2}{*}{ No. } & \multicolumn{2}{|c|}{ Rincian } & \multicolumn{2}{c|}{ November 2014} & \multicolumn{2}{r|}{ Desember 2014} \\
\cline { 3 - 7 } & & \multicolumn{1}{c|}{ Jumlah } & Kepatuhan & \multicolumn{1}{c|}{ Jumlah } & Kepatuhan \\
\hline 1 & Modal BNI Syariah & 2.001 .293 & & 2.010 .915 & \\
\hline 2 & Pihak terkait & & & & \\
\hline & b. BMPK (10\%) & 200.129 & & 201.092 & \\
\hline & c. Total Penyediaan Dana & 16.250 & & 15.963 & $0,79 \%$ \\
\hline & d. Over/ (Under) & $(183.879)$ & ya & $(185.129)$ & ya \\
\hline 3 & Pihak Tidak terkait & & & & \\
\hline & a. BMPK (20\%) & 400.259 & & 402.183 & \\
\hline & b. Nasabah baki debet tertinggi & 194.528 & & 188.725 & $9,39 \%$ \\
\hline & c. Over/(Under) & $(205.731)$ & ya & $(213.458)$ & ya \\
\hline 4 & Pelampauan & \multicolumn{2}{|c|}{ Nihil } & \multicolumn{3}{|c|}{ Nihil } \\
\hline & & \multicolumn{5}{|c|}{} \\
\hline
\end{tabular}

Sumber: Enterprise Risk management Division (ERD)

Adapun Batas Maksimum Penyaluran Dana yang dilakukan di PT. Bank Syariah Mandiri dikemukakan oleh responden A selaku karyawan pada Bank Syariah Cabang Bogor " Batas maksimum penyaluran dana di Bank Syariah mandiri dilakukan di KCP sebesar 500 Juta Rupiah, kemudian Kepala Cabang 2 Milyar Rupiah, Kepala Kanwil, Kepala Divisi dan Direksi. Untuk pembiayaan dengan jumlah dana besar biasanya dilakukan rapat untuk menganalisis kelayakan pemberian kredit. Dana Tujuan adanya Batas Maksimum Penyaluran Dana adalah agar dana yang ada pada bank tidak terserap pada pembiayaan semua. Dan untuk mengurangi risiko gagal kredit. "

\section{7) Transparansi Kondisi Keuangan dan Non Keuangan BUS}

Demi memenuhi transparansi kondisi keuangan dan non keuangan sesuai dengan ketentuan Bank Indonesia, Bank Umum Syariah menyediakan informasi kuantitatif dan kualitatif secara tepat waktu, akurat, relevan dan memadai yang diungkapkan kepada publik dalam rangka. Laporan keuangan dan non keuangan Bank Umum Syariah telah disusun dan disajikan dengan tata cara, jenis dan cakupan yang sesuai dan telah disampaikan kepada pihak- pihak lainnya sebagaimana ketentuan Bank Indonesia. Transparansi kondisi keuangan dalam bentuk kegiatan yang terdiri dari :

a. Transparansi kondisi keuangan diwujudkan dalam laporan pulikasi triwulan kepada bank Indonesia, dalam laporan tahunan secara tepat waktu. 
b. Mengumumkan laporan keuangan publikasi triwulan disurat kabar nasional.

c. Mengirimkan laporan Consolidated Financial Statement (CFS) kepada Bank Indonesia untuk kemudian dimuat dalam homepage Bank Indonesia.

Sedangkan transparansi kondisi non keuangan yang telah diwujudkan oleh Bank Umum Syariah adalah sebagai berikut :

a. Pelaksanaan transparansi informasi produk dilakukan melalui media cetak seperti lefleat, brosur, spanduk promosi dan media elektronik seperti iklan distasiun, TV, radio dan internet, serta didukung dengan kemudahan akses website.

b. Pengaduan nasabah dapat dilakukan dengan menghubungi call center, atau melalui kantor cabang/ kantor pusat. Selain itu pengaduan juga bisa dilakukan melalui whistle blowing system (WBS). Aplikasi WBS dapat digunakan sebagai media untuk mengidentifikasi situasi yang mengarah pada pelanggaran yang terjadi dilingkungan Bank Umum Syariah, baikyang dilakukan pihak internal maupun eksternal perusahaan. Dengan adanya aplikasi WBS tersebut, pegawai maupun masyarakat yang menemukan adanya indikasi benturan kepentingan dapat melaporkannya melalui WBS.

c. Pengaduan yang dilakukan melalui call center atau kantor cabang dikelola oleh divisi operasional. d.

Tabel 8. Kesimpulan Penerapan Good Corporate Governance Pada Bank Umum Syariah Berdasarkan Peraturan Bank Indonesia No.11/33/2009

\begin{tabular}{llll}
\hline No & Faktor & Landasan & $\begin{array}{c}\text { Ketera } \\
\text { ngan }\end{array}$ \\
\hline 1 & Pelaksanaa & PBI No & Sesuai \\
& n tugas & $11 / 33 / \mathrm{PBI} / 2$ & \\
dan & 009 & \\
tanggung & Pasal 8 & \\
jawab & mengenai & \\
Dewan & tugas dan & \\
& Komisaris & tanggung & \\
& & jawab Dewan & \\
\hline
\end{tabular}

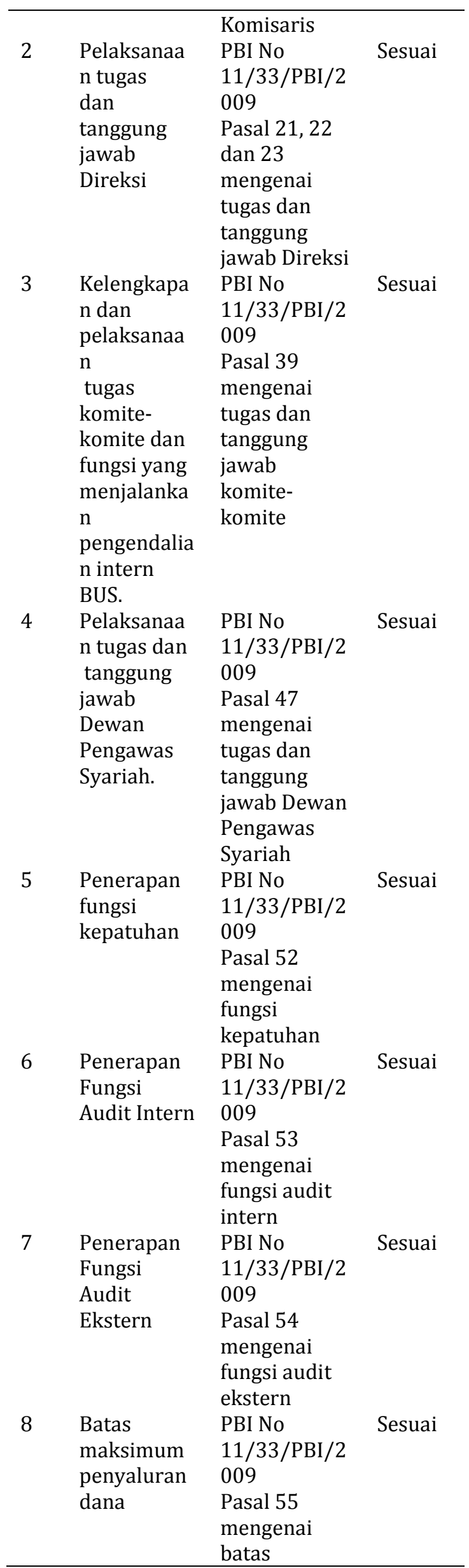




\begin{tabular}{llll}
\hline & & $\begin{array}{l}\text { maksimum } \\
\text { penyaluran } \\
\text { dana }\end{array}$ & \\
$9 \quad$ Transparan & PBI No & Sesuai \\
si kondisi & $11 / 33 / \mathrm{PBI} / 2$ & \\
keuangan & 009 Pasal 56 & \\
dan non & dan & \\
keuangan & 57mengenai & \\
BUS. & $\begin{array}{l}\text { aspek } \\
\text { transparansi }\end{array}$ & \\
& & kondisi BUS & \\
&
\end{tabular}

\section{Sumber : Diolah dari hasil penelitian}

e. Adapun pengaduan melalui whistle blowing system (WBS) akan dikelola oleh divisi Enterprise Risk Management untuk kemudian ditindak lanjuti sesuai dengan tata cara dan prosedur mengenai pengaduan nasabah.

\section{KESIMPULAN DAN IMPLIKASI}

Hasil dari perhitungan kuesioner mengenai prinsip transparency sebesar $83,5 \%$, accountability sebesar $100 \%$, responsibility dengan nilai 96\%, professional sebesar $80 \%$ dan fairness sebesar $96 \%$.

Berdasarkan perhitungan ini secara keseluruhan dapat ditarik kesimpulan bahwa prinsip - prinsip GCG pada Bank Umum Syariah Sangat terwujud dan dapat dikatakan GCG pada Bank Umum Syariah telah diterapkan.

Rumusan masalah kedua mengenai kesesuaian penerapan Good Corporate Governance dengan Peraturan Bank Indonesia No. 11/33/PBI/2009. Berdasarkan PBI No.11/33/PBI/2009 pelaksanaan GCG paling kurang harus diwujudkan dalam :

1. Pelaksanaan tugas dan tanggung jawab Dewan Komisaris dan Direksi telah sesuai dengan pasal 8, 21,22 dan 23.

2. Kelengkapan dan pelaksanaan tugas komite-komite dan fungsi yang menjalankan pengendalian intern BUS telah sesuai dengan pasal 39.
3. Pelaksanaan tugas dan tanggung jawab Dewan Pengawas Syariah telah sesuai dengan pasal 47.

4. Penerapan fungsi kepatuhan, audit intern dan audit ekstern telah sesuai dengan pasal 52, 53, dan 54.

5. Batas maksimum penyaluran dana telah sesuai dengan pasal 55.

6. Transparansi kondisi keuangan dan non keuangan BUS telah sesuai dengan pasal 56 dan 57.

Penelitian ini menunjukan bahwa penerapan Good Corporate Governance pada Bank Umum Syariah telah sesuai dengan Peraturan Bank Indonesia No.11/33/PBI/2009.

\section{DAFTAR PUSTAKA}

Al Qur'an dan terjemahan. 1992 , PT. Tanjung Mas Inti, Semarang

Arbaina, Endang Siti. 2012, Penerapan Good Corporate Governance Pada Perbankan Di Indonesia, Skripsi Sarjana Fakultas Ekonomi Universitas Negeri Surabaya.

Chinn,Richard.2000. Corporate Governance Handbook.Gee Publishing. London

Febriyanti, Diah. 2010, Good Corporate Governance Sebagai Pilar Implementasi Corporate Sosial Responsibilit.(Studi kasus pada PT. Bank X Tbk) Skripsi Sarjana, Fakultas Ekonomi Universitas Dipenogoro.

Fuady, Munir. 2005. Perlindungan pemegang saham minorotas. $\mathrm{CV}$. Utomo Bandung.

Ghozali, Imam.2001, Aplikasi Multivariate dengan program SPSS, Universitas Diponegoro, Semarang

Idroes, Ferry N. 2008. Manajemen Risiko Perbankan. PT Raja Agrafindo Persada Isniarti, 2010. Penerapan Prinsip-Prinsip Good Corporate Governance Pada Dunia Perbankan" Majalah Ilmiah Unikom, Hal 263-269 
Jingga, Violetta. 2011, Penerapan Good Corporate Governance Pada PT.Bank X TBK Kanwil X

Karimah, Aminatul. 2012. Analisis Perbandingan Kinerja Keuangan Perbankan Sebelum Dan Sesudah penerapan GCG, Skripsi Sarjana Universitas Muhammadiyah

Monks, Robert A.G dan Minow N.2003. Corporate Governance $3^{\text {rd }}$ edition. Blackwell Pubilishing.

Organization for Economic Corporation and Development 1999.Prinsip-prinsip (OECD). Corporate Governance.

Peraturan Bank Indonesia Nomor 11/33/PBI/2009 tentang pelaksanaan GCG Bagi Bank Umum Syariah

Putra, Syopiansyah. 2009. Etika Bisnis dan Hak Kekayaan Intelektual, Lembaga Penelitian UIN, Jakarta

Ristifani. 2009, Analisis Implementasi Prinsip-Prinsip GCG dan Hubungannya Terhadap Kinerja PT. Bank Rakyat Indonesia. Tbk, Skripsi Sarjana Fakultas Ekonomi Universitas Gunadarma.

Shaw,Jhon C. 2003. Corporate Governance and Risk : a System approach, Jhon wiley \& sons. Inc. New Jersey

Sedarmayanti,2012. Good Governance \& Good Corporate Governance, CV. Mandar Maju, Bandung

Sugiyono,2012. Metode Penelitian Kuantitatif Kualitatif dan R\&D, Alfabeta, Bandung

Surat Edaran Bank Indonesia No.12/13/DPbs tanggal 30 April 2010 tentang pelaksanaan GCG bagi Bank Umum Syariah dan Unit Usaha Syariah.

Tunggal, Imam Sjahputra. 2002. Membangun Good Corporate Governance. Harvarindo. Jakarta.

Undang-Undang Republik Indonesia No.10 Tahun 1998 mengenai Perbankan.
Usman, Rahmadi. 2001. Aspek-aspek hukum perbankan di Indonesia. PT.Gramedia Pustaka Utama. Jakarta

Wibisono, Darmawan. 2000. Riset Bisnis, BPFE. Yogyakarta 
Jurnal Nisbah Volume 1 Nomor 22015 | 114 